\title{
KONDISI TERUMBU KARANG PULAU MANTEHAGE KABUPATEN MINAHASA UTARA PROVINSI SULAWESI UTARA.
}

\author{
(THE CONDITION OF MANTEHAGE ISLAND CORAL REEFS OF NORTH MINAHASA \\ DISTRICT, NORTH SULAWESI PROVINCE)
}

\author{
Ardy Kase ${ }^{1^{\star}}$, Indri Manembu${ }^{1}$, Joshian Schaduw ${ }^{1}$.
}

1. Program Studi IImu Kelautan, Fakultas Perikanan dan Ilmu Kelautan, Universitas Sam Ratulangi, Manado.

*e-mail : ardyandreas0@gmail.com

Coral reefs are coastal ecosystems with the highest level of diversity. Corals are invertebrates that are included in the Phylum Coelenterata (hollow animal) or Cnidaria. Whereas coral reefs are a collection of millions of polyps. Natural phenomena and various anthropogenic activities threaten the health and presence of Mantehage Island coral reefs and the lack of information about the health conditions of coral reefs on Mantehage Island. The purpose of this study is to determine the condition of coral reefs andto provide baselines data on Mantehage Island. Data collection was done by using UPT method (Underwater Photo Transect). Underwater Photo Transect carried out by underwater shooting using a digital camera that was shielded (housing). Image analysis were done using the CPCe software (Coral Point Count with Excel extensions). The results of coral reef health conditions at four stations on Mantehage Island shows, coral reef cover at each station as follows, station 1 (one) $53.00 \%$ were in good condition, station 2 (two) 25.40\% were in a moderate condition, station 3 (three) 16.49\% were in poor condition, and station 4 (four) $42.07 \%$ were in a moderate condition. From the four stations, the condition of Mantehage Island's coral reefs were in the moderate category with a percentage of $34.24 \%$.

Keywords:. Mantehage Island, Terumbu Karang, UPT, CPCe

Terumbu karang merupakan ekosistem pesisir dengan tingkat keanekaragaman tertinggi. Karang adalah hewan tak bertulang belakang yang termasuk dalam Filum Coelenterata (hewan berongga) atau Cnidaria. Sedangkan terumbu karang adalah kumpulan dari berjuta-juta hewan polip. Fenomena alam dan berbagai kegiatan antropogenik mengancam kesehatan maupun keberadaan terumbu karang Pulau Mantehage dan kurangnya informasi tentang kondisi kesehatan terumbu karang pada Pulau Mantehage. Tujuan penelitian ini adalah mengetahui kondisi terumbu karang dan menyediakan baseline data di Pulau Mantehage. Pengambilan data dilakukan dengan metode UPT (Underwater Photo Transect) atau Transek Foto Bawah Air dilakukan dengan pemotretan bawah air menggunakan kamera digital yang diberi pelindung (housing). Analisis gambar dengan menggunakan piranti software CPCe (Coral Point Count with Excel extensions). Hasil penilaian kondisi kesehatan terumbu karang di empat stasiun pada Pulau Mantehage, tutupan terumbu karang di setiap stasiun adalah sebagai berikut, stasiun 1 (satu) 53,00\% berada pada kondisi baik, stasiun 2 (dua) 25,40\% berada pada kondisi sedang, stasiun 3 (tiga) 16,49\% berada pada kondisi buruk, dan stasiun 4 (empat) $42,07 \%$ berada pada kondisi sedang. Dari keempat stasiun pengambilan data kondisi terumbu karang Pulau Mantehage masuk dalam kategori sedang dengan persentase $34,24 \%$..

Kata kunci: Pulau Mantehage, Terumbu Karang, UPT, CPCe. 


\section{PENDAHULUAN}

Terumbu karang merupakan ekosistem pesisir dengan tingkat keanekaragaman tertinggi dengan jumlah sekitar satu juta spesies di seluruh dunia (Reaka-Kudla, 1997). Karang adalah hewan tak bertulang belakang yang termasuk dalam Filum Coelenterata (hewan berongga) atau Cnidaria. Sedangkan terumbu karang adalah kumpulan dari berjuta-juta hewan polip yang menghasilkan zat kapur yang hidup di skeletonnya dan berkembang membentuk hamparan koloni yang luas (Thamrin, 2006). Terumbu karang didiami berbagai macam biota laut yang merupakan sumber protein dari laut dan sumber bahan baku yang berguna dalam farmasi dan kedokteran. Terumbu karang sebagai ekosistem yang memiliki keindahan yang bernilai tinggi dan sangat potensial sebagai daya tarik pariwisata. Selain itu terumbu karang juga dikenal sebagai benteng alami yang berfungsi melindungi pulau dan pantai dari bahaya abrasi yang disebabkan oleh gempuran ombak.

Provinsi Sulawesi Utara memiliki 258 pulau yang tersebar di 10 Kabupaten dan kota. Jumlah pulau yang berpenghuni adalah 59 pulau dan jumlah yang tidak berpenghuni adalah 199 pulau. Dari jumlah 258 pulau, terdapat 11 pulau kecil terluar dan 3 pulau di antaranya yang merupakan pulau perbatasan negara Indonesia dengan Filipina. Salah satu pulau kecil terluar adalah Pulau Mantehage yang di mana sudah ditetapkan dari Tahun 1991 sebagai wilayah Taman Nasional Bunaken berdasarkan SK. MENHUT NO.730/Kpts11/1991. Ekosistem yang ada di Pulau Mantehage dapat dimanfaatkan secara baik untuk kepentingan ekonomi, ekologi maupun penelitian. Karena keragaman dan keindahan ekosistem laut terutama terumbu karang yang tidak jauh berbeda dengan Pulau Bunaken, sehingga perlu dilakukan pemantauan dan penelitian lebih lanjut tentang kondisi terumbu karang pada daerah tersebut.

Perkembangan metode yang dipakai untuk menilai kondisi terumbu karang di dunia dalam beberapa dekade belakangan mulai era tahun 1970-2000 terus berkembang. Beragam metode yang digunakan tersebut tidak terlepas dari adanya kelemahan baik dari segi teknis pelaksanaan lapangan, kemampuan sumber daya manusia, maupun besarnya anggaran biaya yang diperlukan dalam penerapan masing-masing metode. Menurut Giyanto (2013) penggunaan metode Manta Tow (English et al., 1994; Sukmara et al., 2001) dapat menjangkau daerah penelitian yang lebih luas dengan waktu yang lebih singkat, tetapi akan sulit dan berbahaya jika dilakukan pada daerah yang penuh dengan karang keras yang berbentuk masif dengan ukuran besar.

Penggunaan metode Line Intercept Transect (LIT) (English et al., 1994; Hill and Wilkinson, 2004) diperlukan waktu yang lebih lama dibandingkan dengan metode Manta Tow, serta dibutuhkan kemampuan seseorang untuk menyelam dan kemampuan untuk mengidentifikasi karang sampai tingkat jenis. Kelemahan pengambilan data dengan menggunakan metode Reef Resource Inventory (RRI) adalah data yang terambil tidak selengkap data yang diambil dengan menggunakan metode LIT.

Kebutuhan informasi spasial terumbu karang yang detail dan akurat dari komposisi, status dan dinamika terumbu karang adalah persyaratan mutlak dalam proses konservasi dan manajemen ekosistem terumbu karang yang berkelanjutan (Phinn et al., 2012). Menanggapi hal tersebut, maka dalam penelitian kali ini diterapkan metode foto transek bawah air, di mana setiap foto yang diambil akan memiliki informasi spasial, pertama kali diperkenalkan oleh Roelfsema and Phinn (2010). Informasi spasial terumbu karang Pulau Mantehage yang detail dan akurat dibutuhkan dalam rangka kegiatan pemantauan (monitoring) ekosistem terumbu karang. Informasi spasial sebaran terumbu karang yang detail dan akurat ini juga sangat diperlukan oleh para pengambil kebijakan dalam penentuan arah pengembangan Pulau Mantehage di masa datang. Tujuan dari penelitan ini adalah : 1) Untuk mengetahui kondisi terumbu karang di Pulau Mantehage. 2) Menyiapkan 
baseline data kondisi terumbu karang Pulau Mantehage.

\section{METODE PENELITIAN}

\section{Waktu dan Tempat Penelitian}

Penelitian ini dilakukan di Pulau Mantehage Kabupaten Minahasa Utara Provinsi Sulawesi Utara. Kegiatan penelitian dilakukan pada daerah terumbu karang dimana dilakukan pada 4 stasiun di sekitar Pulau Mantehage yang masingmasing areanya di plot dalam peta, dapat dilihat pada Gambar 1 dan titik koordinatnya dapat dilihat pada Tabel 1.

Tabel 1. Titik Kordinat Pengambilan Data

\begin{tabular}{|c|c|c|}
\hline Stasiun & Utara & Timur \\
\hline 1 & $01^{\circ} 43^{\prime} 20,8^{\prime \prime}$ & $124^{\circ} 46^{\prime} 30,8^{\prime \prime}$ \\
\hline 2 & $01^{\circ} 42^{\prime} 40,7^{\prime \prime}$ & $124^{\circ} 47^{\prime} 00,8^{\prime \prime}$ \\
\hline 3 & $01^{\circ} 41^{\prime} 27,5^{\prime \prime}$ & $124^{\circ} 46^{\prime} 20,7^{\prime \prime}$ \\
\hline 4 & $01^{\circ} 41^{\prime} 23,3^{\prime \prime}$ & $124^{\circ} 46^{\prime} 05,3^{\prime \prime}$ \\
\hline
\end{tabular}

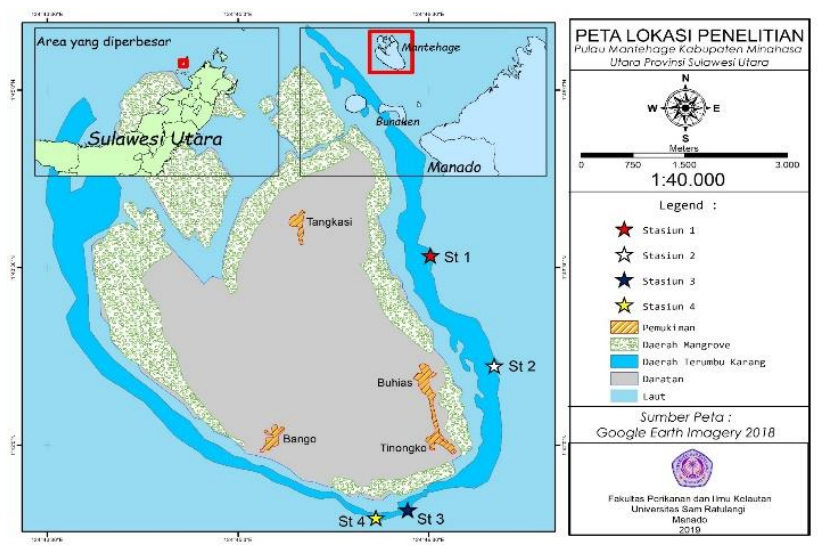

Gambar 1. Peta Pengambilan Sampe

\section{Pengambilan data}

Metode Transek foto bawah air atau Underwater Photo Transect (UPT) merupakan metode yang memanfaatkan perkembangan teknologi, baik perkembangan teknologi kamera digital maupun teknologi piranti lunak komputer. Pengambilan data di lapangan berupa foto-foto bawah air yang dilakukan dengan pemotretan menggunakan kamera Canon G-16 yang dilengkapi housing (Giyanto, dkk. 2014) tapi tidak harus juga menggunakan Canon G-16 bisa juga menggunakan kamera lain yang memiliki kualitas atau resolusi gambar yang bagus atau besar, di mana dalam setiap lokasi ditarik meter dengan jarak 50 meter menggunakan roll meter dan setiap stasiun terdapat 50 buah foto..

\section{Analisis Foto}

Untuk mendapatkan data-data kuantitatif berdasarkan foto-foto bawah air yang dihasilkan dari motede UPT ini, analisis data dilakukan terhadap setiap frame dengan cara melakukan pemilihan sampel titik acak. Titik ini digunakan dengan menentukan banyaknya titik acak (random point) yang dipakai untuk menganalisis foto. Jumlah titik acak yang digunakan adalah sebanyak 30 buah titik acak untuk setiap framenya, dan ini sudah representative untuk menduga persentase tutupan kategori dan substrat

(Giyanto, 2013). Teknik ini merupakan aplikasi dari penarikan sampel, dimana sebagai populasinya adalah titik-titik yang dipilih secara acak pada foto tersebut. Dengan cara ini, data yang dicatat hanyalah biota dan substrat yang berada tepat pada posisi titik yang telah ditentukan secara acak oleh piranti lunak CPCe.

Coral Point Count with Excel extension (CPCe) merupakan suatu aplikasi komputer yang dapat digunakan untuk menghitung luasan dari substrat dasar dari suatu foto hasil pengamatan yang menggunakan kamera digital bawah air. Selain dapat digunakan untuk menghitung persentase tutupan substrat dasar dengan metode point count, dapat juga digunakan dengan cara menghitung luasan dari masing-masing tipe substrat dasar yang akan dianalisis.

Berdasarkan proses analisis foto yang dilakukan terhadap setiap frame foto, maka dapat diperoleh nilai persentase tutupan kategori untuk setiap frame dihitung berdasarkan rumus (Giyanto $d k k$., 2014) sebagai berikut :

\section{Persentase Tutupan Kategori $=$} $\frac{\text { (jumlah titik kategori tersebut) }}{\text { (banyaknya titik acak })} \times 100$ 
HASIL DAN PEMBAHASAN

Hasil dari pengambilan data yang dilakukan di perairan Pulau Mantehage berupa foto-foto yang telah diolah dengan menggunakan aplikasi CPCe maka hasil yang dapat dilihat dari ke 4 (empat) stasiun adalah sebagai berikut :

\section{Kondisi Terumbu Karang di Stasiun 1}

Kondisi terumbu karang di Stasiun 1 berada pada kategori baik dengan persentase $53 \%$ hard coral, $12,53 \%$ death coral, $2,20 \%$ soft coral, $13,87 \%$ patahan karang, dan 16,53\% biota lain. Untuk melihat persentase struktur komunitas pada stasiun 1 dapat dilihat pada Gambar 9. Kondisi ini disebabkan karena kondisi pada stasiun 1 memiliki 3 ekosistem pesisir yang lengkap mulai dari mangrove, lamun, dan terumbu karang dapat dilihat pada peta lokasi penelitian (Gambar 1). $\mathrm{Hal}$ ini dikarenakan mangrove dan lamun dapat menahan sedimentasi yang berasal dari darat sehingga pertumbuhan karang lebih baik dikarenakan kurangnya sedimentasi yang berasal dari daratan.

\section{Kondisi Terumbu Karang di Stasiun 2}

Kondisi terumbu karang di Stasiun 2 berada pada kategori buruk dengan persentase $25,40 \%$ hard coral, $9,60 \%$ death coral, 0,47\% soft coral, $46,80 \%$ patahan karang, $0,07 \%$ sponge dan $17,67 \%$ biota lain. Untuk melihat persentase struktur komunitas pada stasiun 2 dapat dilihat pada Gambar 10. Kondisi perairan pada stasiun 2 tidak memiliki ekosistem mangrove menyebabkan sedimen dari darat masuk ke laut dan aktivitas antropogenik sangat berpengaruh pada stasiun ini contohnya seperti aktivitas dekat dermaga. Hal ini dijelaskan oleh Schaduw., (2018) mengenai kondisi perairan di depan Pulau Mantehage memiliki nilai di bawah baku mutu kekeruhan yaitu (4,45 NTU), inilah salah satu faktor penyebab kondisi terumbu karang pada stasiun ini buruk.

\section{Kondisi Terumbu Karang di Stasiun 3}

Kondisi terumbu karang di Stasiun 3 berada pada kategori buruk dengan persentase $16,49 \%$ hard coral, 15,75\% death coral, 4,36\% soft coral, 51,68\% patahan karang, $1,21 \%$ sponge, pasir $4,36 \%$, batuan $0,13 \%$ dan $5,76 \%$ biota lain. Untuk melihat persentase biota pada stasiun 3 dapat dilihat pada Gambar 11. Kondisi pesisr pada stasiun ini memiliki 3 ekosistem yang lengkap dari mangrove, lamun dan terutama terumbu karang akan tetapi kondisi terumbu karang pada stasiun ini sangat buruk yaitu $16,49 \%$ dan yang lebih dominan merupakan patahan karang dapat dikatakan pada lokasi ini terpengaruh oleh aktivitas nelayan yang masih menggunakan bom ikan dan sianida sehingga merusak kondisi terumbu karang pada stasiun 3.

\section{Kondisi Terumbu Karang di Stasiun 4}

Kondisi terumbu karang di Stasiun 4 berada pada kategori sedang dengan persentase $42,07 \%$ hard coral, 1,53\% death coral, 1,53\% soft coral, 33,33\% patahan karang, $1,21 \%$ sponge, pasir $2,67 \%$, dan $13,47 \%$ biota lain. Untuk melihat persentase biota pada stasiun 1 dapat dilihat pada Gambar 12. Lokasi pada stasiun 4 tidak terlalu jauh dari stasiun 3 tetapi kondisi pada stasiun 4 masuk dalam kategori sedang dikarenakan pada stasiun 4 memiliki 3 ekosistem pesisir yang lengkap dan masih sedikit dipengaruhi oleh aktivitas nelayan yang menggunakan bom ikan dan sianida sebagai alat tangkap.

\section{KESIMPULAN}

Dari 4 stasiun pengamatan kondisi terumbu karang di Pulau Mantehage, didapatkan 3 (tiga) kategori kondisi terumbu karang, yaitu kondisi baik, sedang dan buruk. Jika dilihat kondisi terumbu karang dari setiap stasiun, didapatkan stasiun 1 berada dalam kategori baik dengan persentase $53.00 \%$, stasiun 2 berada dalam kategori sedang dengan persentase $25,40 \%$, stasiun 3 berada dalam kategori buruk dengan persentase $16,49 \%$, dan stasiun 4 berada dalam kategori sedang dengan persentase $42,07 \%$, maka presentase keseluruhan Pulau Mantehage adalah $34,24 \%$. 


\section{DAFTAR PUSTAKA}

English, S., Wilkinson. and C. V. Baker. 1994. Survey Manual for Tropical Marine Resources. Australia: ASEAN - Australia Marine Science Project Living Coastal Resources.

Giyanto. 2013. Metode Transek Foto Bawah Air untuk Penilaian Kondisi Terumbu Karang. Oseana. Vol. XXXVIII. No. 1. Hal 47-61.

Giyanto., A. Ew Manuputty., M. Abrar., R. $M$ Siringoringo., S. R Suharti., K. Wibowo., I. N E. U. Y. Arbi., H. A. W. Cappenberg., H. F. S. Y. Tuti. dan D. Zulfianita. 2014. Panduan Monitoring Kesehatan Terumbu Karang. Pusat Penelitian Oseanografi-LIPI. 77 hal.

Hill, J. and Wilkinson. 2004. Methods for Ecological Monitoring of Coral Reefs. Versi ke-1, A Resources Formanagers. Australian Institute of Marine Science, 2004. 116 hal.

Keputusan Menteri Kehutanan No. 730/ KPTS- II/ 1991. Tentang Perubahan Fungsi Cagar Alam Laut Bunaken, Manado Tua, Arakan, Wowon, Tulap, di Kabupaten Daerah Tingkat II Minahasa, Provinsi Daerah Tingkat I Sulawesi Utara Seluas 89. 065 Hektar menjadi Taman Nasional.

Phinn, S. R., C. M. Roelfsema. and P. J. Mumby. 2012. Multi Scale, ObjectBased Image Analysis for Mapping Geomorphic and Ecological Zones on Coral Reefs.International Journal of Remote Sensing. Vol 33(12). Hal 3768-3797.

Reaka, K. M. L. 1997. The Global BiodiVersity Of Coral Reefs: A Comparison With Rain Forests.In: Reaka-Kudla ML, Wilsonde, And Wilson EO, Editors.Biodiversity II: Understanding And Protecting Our Biological Resour-Ces, Washington: Joseph Henry Press. Hal 83-107.

Roelfsema, C. M. and S. R. Phinn. 2010. Integrating field data with high spatial resolution multispectral satellite ima-gery for calibration and validation of coral reef benthic community maps.J.of Applied Remote Sensing. Vol 4(1). Hal 0128.

Schaduw, J. N. W. 2018. Distribusi dan Karakteristik Kualitas Perairan Ekosistem Mangrove Pulau Kecil Taman Nasional Bunaken. Majalah Geografi Indonesia. Vol. 32. No. 1. Hal 40-49.

Sukmara, A., A. J. Siahainenia. dan C. Rotinsulu . 2001. Panduan Pemetaan Terumbu Karang Berbasis-Masyarakat Dengan Metodemanta Tow. Jakarta: Proyek Pesisir-CRMP Indonesia. Hal 48

Thamrin. 2006. Karang: Biologi Reproduksi dan Ekologi. Minamandiri Press. Pekanbaru. 